\title{
ЛІНГВОПЕРСОНА ЛІНИ КОСТЕНКО: АКТУАЛІЗАЦІЯ ФРАЗЕОЛОГІЗМІВ У ЇЇ ПОЕТИЧНИХ ТЕКСТАХ
}

\author{
АННА ФІЛІП'ЯК \\ Університет імені Адама Міцкевича, Познань - Польща \\ afilipiak66@gmail.com; ORCID: 0000-0001-5203-194X \\ OSOBOWOŚĆ JEZZYKOWA LINY KOSTENKO: \\ AKTUALIZACJA FRAZEOLOGIZMÓW W JEJ TEKSTACH POETYCKICH \\ ANNA FILIPIAK \\ Uniwersytet imienia Adama Mickiewicza, Poznań — Polska
}

STRESZCZENIE. Niniejszy artykuł poświęcono analizie związków frazeologicznych wykorzystanych przez Linę Kostenko w poetyckim tomie Tpucma nоeзiü. Opisano fenomen osobowości językowej, wskazując na fakt, iż Lina Kostenko bez wątpienia należy do jednej z najbardziej jaskrawych osobowości językowych w literaturze ukraińskiej. Wspomniane frazeologizmy poddano analizie, uwzględniając ich podział na wyrażenia słownikowe, autorskie oraz aforyzmy. Zaproponowano właściwe tendencje, a także określono perspektywę badań.

Słowa kluczowe: idiom, osobowość językowa, tekst poetycki.

\section{ELIGIBLE PERSONALITY OF LINA KOSTENKO'S LANGUAGE: FUNCTIONING OF IDIOMS IN HER POETIC WORKS}

\author{
ANNA FILIPIAK \\ Adam Mickiewicz University, Poznań — Poland
}

ABSTRACT. This article focuses on the analysis of the phraseological links used by Lina Kostenko in the collection of the poetry "Trysta poeziy". The phenomenon of a linguistic personality has been described, pointing to the fact that Lina Kostenko undoubtedly belongs to one of the most vivid linguistic personalities in Ukrainian literature. The idioms have been analyzed, including their division into the lexical phrases, the author-made the phrases and the aphorisms. The right tendencies have been also proposed and the perspective of the research has been defined.

Key words: idioms, linguistic personality, poetic text.

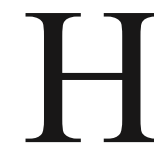

а поч. XXI ст. мовознавці почали особливо цікавитися проблемою опису особистості як основного складника наукової мовної картини світу. Сучасна лінгвістика, зокрема, зосереджується на вивченні зв'язків людини з мовою, тобто на проблемі мовної особистості як людини в їі здатності до мовленнєвих учинків, сукупності всіх мовних здібностей і реалізацій особистості в мовленні.

Дослідженню індивідуального стилю письменника через мову його творів присвячено чимало праць. В українському мовознавстві це роботи Н. Дужик, С. Срмоленко, Л. Зіневич, Т. Космеди, В. Масальського, Л. Мацько, А. Мойсієнка, Н. Сологуб, Л. Ставицької, М. Сулими, Г. Сюти, Г. Удовиченка, О. Цапок 
та ін. Серед цих розвідок і такі, що репрезентують мовну особистість Ліни Костенко (Н. Буц, Г. Вокальчук, Г. Губарєва, Н. Касьяненко, М. Мельник) ${ }^{1}$.

Учені стверджують, що термін лінгвоперсонологія запропонував В. Нерознак із метою номінації мовознавчої дисципліни, об'єктом якої є мовна особисmicms та іiї аналіз (чинники формування, становлення й розвитку) 2 .

Відомо також, що термін мовна особистість першим почав використовувати в процесі опису мовця як автора художнього твору відомий російській мовознавець В. Виноградов ${ }^{3}$.

Зауважимо, що мовна особистість включає систему комунікативних характеристик мовної поведінки: визначення ії типів, установлення мовних портретів та ідіостилів, адже, на думку IO. Караулова, „неможливо пізнати мову як таку, не виходячи за їі межі, не звертаючись до іiі творця, носія - до людини, конкретної мовної особистості” (переклад. автор. - А. Ф.) ${ }^{4}$.

Отже, сучасні лінгвісти під терміном мовна особистісь розуміють конкретного носія мови, який здатний створювати, усвідомлювати й відтворювати тексти. Учені описують мовну особистість на підставі аналізу текстів, створених нею. При цьому кожна мовна особистість здатна використовувати характерні засоби мови, стилістики, орнаменталіки 3 метою репрезентації індивідуального бачення довкілля.

Зазначимо також, що поняття мовна особистість містить не тільки лінгвістичні, але й психологічні та соціальні ознаки, створюючи нові можливості для подальшого іiі дослідження. Мовна особистість - призма, крізь яку відбувається бачення та категоризація явищ довкілля, що репрезентує й низку національно-культурних факторів, які моделюють мовну картину світу5.

Репрезентація мовної особистості — твория тексту, як переконані дослідники, передбачає:

а) характеристику семантичного рівня,

б) опис індивідуальних відмінностей у семантиці тексту,

в) реконструкцію моделі світу (фрагмента), що відображена у свідомості,

г) мотиви, інтенції, домінанти, особливості сприйняття, світовідчуття, а також те, які поняття і як саме виражаються цією особистістю, яким стилем, якими способами й засобами мовленнєвої комунікаціїб.

${ }^{1}$ Н. В. Буц, Специфіка ментального лексикону: мовний етикет у творах Ліни Костенко, [в:] „Ученые записки Таврического национального университета им. В. И. Вернадского”, серия „Филология. Социальные коммуникации”, Симферополь 2011, т. 24 (63), № 4, ч. 1, с. 431-434; Г. А. Губарева, Семантика та стилістичні функиії кольоративів у поетичній мові Ліни Костенко, автореф. дис. ... канд. філол. наук, Харків 2002; Н. М. Касьяненко, Концепт слово $в$ поетичній картині світу Ліни Костенко, [в:] „Вісник Донецького національного університету, Сер. Б: Гуманітарні науки", 2013, вип. 1-2, т. 1, с. 120-126; М. Р. Мельник, Ономастика творів Ліни Костенко, автореф. дис. ... канд. філол. наук, Одеса 1999; Л. П. Петрова, Власне ім'я як засіб інтелектуалізаиї (на матеріалі поезї Ліни Костенко), автореф. дис. ... канд. філол. наук, Харків 2003.

2 Див. про це, напр., Т. Космеда, Ego i Alter Ego Tapaca Шевченка в комунікативному просторі щоденникового дискурсу, Дрогобич 2012.

${ }^{3}$ Див. там само.

${ }^{4}$ См.: Ю. Н. Караулов, Русский язык и языковая личность, Москва 1987, с. 50-53.

${ }^{5}$ Г. І І. Крохмальна, Терміни в ідіостилі вченого, автореф. ... дис. канд філол. наук, Львів 2011, с. 12-15.

${ }^{6}$ Л. І.Маць ко, Мовна особистість Андрія Малишка як лінгвокультурологічний феномен національного виховання у світлі лінгвофілософії, [в:] „Науковий часопис НПУ імені М. П. Драгоманова", сер. 16: Творча особистість учителя: проблеми теорії і практики, Київ 2013, вип. 20, c. $141-146$. 
На думку А. Загнітка, мовна особистість - це поєднання мовної компетенції, прагнення до творчого самовияву, вільного, автоматичного здійснення всебічної мовленнєвої діяльності, гармонійного існування в мовному колективі та передусім власної мовної самоідентифікації. Таким чином, мовна особисmicms - вияв соціально-територіального середовища й традицій виховання.

Мовну особистість у комунікативній лінгвістиці розглядають як типового, зразкового або самобутнього мовця (носія відповідної мови), якого характеризують його мовленнєві стратегії й тактики?

Підсумуємо: мовна особистість - багаторівневе поняття, синтез лінгвістичної та психологічної основ; неможливим є ії повноцінний аналіз за умови врахування тільки одного з іiі аспектів. Вона характеризується також суперечністю співвідношення стабільних та змінних елементів, сталістю мотивацій і здатністю підпорядкуватися не тільки зовнішнім впливам, але також і самовпливу ${ }^{8}$.

Мета цієї наукової розвідки - розглянути особливості вияву мовної особистості Ліни Костенко щодо специфіки залучення в її поетичний текст фразеологічних мовних засобів.

Творчість Ліни Костенко стала важливим явищем сучасної української поезії, що значно впливає на весь $\dddot{11}$ подальший розвиток. Репрезентуючи національні ідеали й найкращі риси живої народної мови, ідейну вагомість та образну довершеність, вона підносить українську літературу на рівень найкращих зразків європейської художньої творчості. Особливості індивідуального поетичного стилю поетеси - це передусім висока культура поетичного вислову, новаторство, інтелектуальність, високий рівень мовної свідомості й інтертекстуальність.

Ліна Костенко як одна з найбільш відомих письменниць України володіє надзвичайною образністю висловлювання, що, безумовно, значно збагачує сучасну українську мову. У щоденне вживання ввійшло вже чимало авторських неологізмів і трансформованих фразеологізмів, властивих стилю письменниці. Нові авторські вислови поетеси, трансформації в зафіксованих словосполученнях $\epsilon$ неоціненним джерелом для подальшого розвитку сучасної української мови.

Питання щодо творення нових фразеологізмів як мовно-історичного та мовно-культурного явища набувають у сучасному українському мовознавстві особливої актуальності в аспекті вивчення семантики та прагматики фразеологічних одиниць унаслідок їхнього тривалого розвитку, стабілізації й закріплення в мовленнєвій практиці народу. Його динаміка полягає в певних лексикограматичних перетвореннях, змінах, що простежуються як у синтаксично вільних словосполученнях, так і семантично нерозкладних фразеологізмах 9 .

Звернемо увагу, що поетичне мовлення Ліни Костенко насичене фразеологізмами, серед яких простежуємо певне розмаїття - узуальні й трансформовані фразеологізми, крилаті вислови та афоризми, що вдало передають і закріплюють художню й естетичну оцінку дійсності, створену письменницею. Безумовно, узуальні фразеологізми, тобто фразеологізми, зафіксовані в чинних словниках української мови, є лінгвістичними об'єктами, до яких звертаються практично всі письменники.

${ }^{7}$ А. Загнітко, Н. Загнітко, Теорія сучасної лінгвоперсонологї̈: рівні й категорї̈, [w:] „Studia Ukrainica Posnaniensia”, red. nauk. T. Kosmeda, zesz. IV, 2016, c. 17-20.

${ }^{8}$ T. Космеда, Ego i Alter Ego Tapaca Шевченка..., с. 24-26.

${ }^{9}$ I. В. Ке в люк, Термін фразема в етнолінгвістиці та культурології, [в:] „Структура і семантика мовних одиниць, Філологічні студії”, вип. 6, Київ 2011, с. 250. 
На матеріалі аналізу збірки поезій Ліни Костенко під назвою Триста поезій ${ }^{10}$ можна виокремити систему сполучень слів, що зафіксовані у фразеологічних словниках й активно відтворюються у творчості поетеси. Це такі фразеологічні одиниці, як Не боляче йому, бо він розбився на камінні друзки [27] - 'розбитися повністю, дощенту, на дрібні шматочки'; Блукали руки десь на манівцях [37] - 'робити щось без чітких орієнтирів, навмання', Якщо живим не можна вийти звідси, - вперед ногами винесуть мене [48] - 'померти' [29]; Гострила вухо темрява у шклі [58] - 'напружено, уважно прислухатися до чогось (людей); зосереджуючись і прислухаючись, піднімати догори вуха (про тварин)'; Не бійся, я не покладаю рук [64] - 'невтомно, сумлінно, із великим завзяттям трудитися, працювати'; Може, ие біль наш, а, може, вина, може, бальзам на занедбані душі [76] - 'слова підтримки або радісна звістка' [24]; Душа до краю добрела [78] - 'зовсім, повністю, остаточно, дуже сильно, надзвичайно, зі словами поговорити, порозмовляти, остаточно, скільки стане сил'.

Трансформація фразеологізмів, у якій, за словами В. Ужченка, „автор ніби дає нове життя відомій, із дещо втраченими художніми характеристиками, фразеологічній одиниці, робить ії подвійно виразною, оскільки до пов'язаного із цією формулою традиційного загального значення додаються нові індивідуальні значення, котрі суміщаються в єдиному поетичному образі" 11, є дуже важливим процесом у творенні нових фразеологічних одиниць. Давній структуpi, із пригаслою від частого вживання образністю, повертається експресивність, надана новим контекстом. Знайоме сполучення слів, що вживається, власне, у тому самому вигляді з іншим відтінком, якого надає йому новий елемент у його структурі, починає звучати із семантико-експресивними нарощеннями, контекстно-актуально, з новою прагматикою. Авторська експресія по-новому оживлює вираз, подає об'єкт відчутно випукло ${ }^{12}$.

Кожен історичний період, залежно від актуальних подій і соціальнокультурних умов, створював усталені звороти, що з часом почали архаїзуватися шляхом відсторонення з художньої літератури. Частина з них уже втратила актуальність або набрала нового змісту. У творчості Ліни Костенко знаходимо трансформовані фразеологізми, що частково або повністю змінили значення.

Напр., у фразеологізмі сльоза чомусь набізла до повік [59], що актуалізується в значенні 'хто-небудь готовий заплакати', відбувається оновлення граматичної оболонки фразеологічної одиниці, а саме: відбувається заміна множини одниною і лексична трансформація, тобто заміна одного з компонентів синонімом; Курбас ліг у ту промерзлу землю! [75] — 'померти, загинути' — відбувається контамінація двох фразеологічних зворотів з розширенням лексичної структури: простежуємо додавання атрибутивного компонента промерзла, що підсилює емоційний вплив на реципієнта; I смерть впритул до мене підсту$n a$ [96] - 'хто-небудь скоро помре': тут поетеса використовує фразеологічний зворот як образ, уводячи його в структуру іншого загальновживаного фразеологічного звороту підступати впритул; Пройшла зачароване коло [129]: зачароване коло - це 'скрутне, безвихідне становище' - відбувається розширення лексико-граматичного складу за рахунок додавання компонента зі значенням дії, що, відповідно, й змінює семантику і прагматику цього фразеологізму;

${ }^{10}$ Л.В.Ко с тен ко, Триста поезій, Київ 2012. - Далі під час наведення прикладів за цим виданням у квадратних дужках указуватимемо конкретну сторінку.

${ }^{11}$ В. Д. Ужченко, Д. В. Ужченко, Фразеологія сучасної украйнської мови, Київ 2007, c. 215.

${ }^{12}$ Там само. 
Істини одвічні [135]: прописна істина 'загальновідома, елементарна річ', де прописний - 'загальновідомий, банальний, шаблонний, спрощений, “як у прописах"”. У цьому разі поетеса зберігає лексико-граматичну цілісність фразеологічного звороту, але із заміною одного компонента синонімом, що відповідає сучасним реаліям життя (прописна - одвічна); Така любов буває раз в ніколи [138] (раз на віку — 'дуже рідко') — використання фразеологічного звороту із заміною одного із компонентів, що надає вислову іронічного, парадоксального, більш напруженого й експресивного значення.

Окрім традиційного фразеологізму, прийнятним є також термін, що визначає індивідуально-авторський фразеологічний новотвір (індивідуальний, оказіональний, контекстний). Роль таких новотворів у мові Ліни Костенко виявляється у вмінні оригінально поєднати слова, підібрати незвичне означення, а також поєднати відмінні в семантичному або часовому контексті поняття. Прикладами таких новотворів можна вважати крилаті вислови й афоризми.

Безперечно, афоризми здатні створювати тільки ті люди, які володіють мовною креативністю; це вимагає наявності досконалої мовної компетенції, дотепності та винахідливості, уміння сприймати смисл тексту гнучко мислячи та неоднозначно сприймаючи світ. Афоризми часто стають життєвими девізами, завдяки наявності в їхній структурі чуттєвих цінностей, образів, переконань, знань чи поглядів.

У поетичній творчості Ліни Костенко можна виокремити такі крилаті вислови, що водночас поєднують смислові та культурні інтерпретаційні схеми, порівн.: Найкращий вірш не ходить на свободі; Чи нас Господь почує усіх разом, коли так просить кожен про своє?; Коли в людини є народ, тоді вона уже людина; Нерівня душ - ие гірше, ніж майна!; У пеклі наших доль не знаєш сам - ти бранеиь чи обранець; Лиш народи, явлені у Слові, достойно жити можуть на землі; Здушили сльози - не виходь на люди. Болить душа - не виявляй на вид; Страшні слова, коли вони мовчать; Де є та грань - хто люди, хто юрма?; Душа, зруйнована, як Троя, своїх убивщь переживе; О найстрашніше з літочислень - війна війною до війни!; Якщо платити злочином за злочин, то як же й жити... на землі; Душа летить в дитинство, як у вирій, бо ій на світі тепло тільки там; Де воля спить, ї̈ ще й приколишуть; Поразка - ие наука. Ніяка перемога так не вчить; Сдиний, хто не втомлюсться, - час; Самотнім добре - жодної розлуки; Всі слова уже були чиїмись; Од звичайного погляду скрите відкривається лиш дивакам; Хіба це мало - незабутня мить?; А слово - струм. А слово - зброя. А віще слово - вічове; Не було епохи для поетів, але були поети для епох!.

Отже, навіть стислий аналіз поезії Ліни Костенко дає змогу стверджувати, що процес творення нових фразеологічних одиниць у сучасному українському лінгвокультурному просторі є досить активним насамперед завдяки креативній діяльності мовних особистостей. Цьому сприяє поява нових фразеологічних засобів - новоутворених або оновлених усталених виразів, які маємо право так номінувати тільки за умови, якщо вони відсутні в чинних академічних словниках. Цей процес реалізується шляхом (а) переосмислення вільних словосполучень, (б) застосування парафразування, (в) створення нових образних одиниць або (г) парадоксального поєднання слів способом трансформації старих чи нових одиниць за аналогією 3 ними. Так формуються індивідуально-авторські фраземи, що мають статус нових. 
Ліна Костенко як одна 3 найбільш відомих українських письменників, вишукана мовна особистість сучасності робить, безперечно, вагомий унесок у розвиток сучасної української мови, іiі фразеології.

Досконале вміння письменниці щодо оперування словом чи сполученням слів, здатність переносити їх в інші семантичні та прагматичні простори, як бачимо, сприяє створенню авторських фразеологічних одиниць, що збагачують та прикрашають літературну мову українців. Чимало з них увійшло в щоденне мовлення українців.

Зауважимо, що в наші дні мовна культура загалом має значний вплив на формування нових фразеологізмів, зокрема й трансформованих, а також афоризмів. Зміни в соціальному та політичному житті суспільства спричиняють актуалізацію вишуканими, елітарними мовними особистостями, зокрема й Ліною Костенко, низки фразеологізмів, що були застарілими, відживлюючи їх. Більшість 3 виразів, що характеризуються семантичною гнучкістю, виразною прагматикою, активно сприймаються в суспільстві, переходячи 3 одного мовного оточення до іншого й міцно закріплюючись у мовленні наших сучасників, роблячи його також більш експресивним, виразним, образним, привабливим.

\section{Список використаної літератури}

Буц Н. В., Специффіка ментального лексикону: мовний етикет у творах Ліни Костен$\kappa o$, [в:] „Ученые записки Таврического национального университета им. В. И. Вернадского”, серия „Филология. Социальные коммуникации”, Симферополь 2011, т. 24 (63), № 4, ч. 1, c. 431-434.

Губарева Г. А., Семантика та стилістичні функиії кольоративів у поетичній мові Ліни Костенко, автореф. дис. ... канд. філол. наук, Харків 2002.

Загнітко А., Загнітко Н., Теорія сучасної лінгвоперсонології: рівні й категорї, [w:] „Studia Ukrainica Posnaniensia", red. nauk. T. Kosmeda, 2016, zesz. IV, s. 17-20.

Караулов Ю. Н., Русский язык и языковая личность, Москва 1987.

Касьяненко Н. М., Концепт слово в поетичній картині світу Ліни Костенко, [в:] „Вісник Донецького національного університету, Сер. Б: Гуманітарні науки”, 2013, вип. 1-2, т. 1, с. 120-126.

Кевлюк І. В., Термін фразема в етнолінгвістиці та культурології, [в:] „Структура і семантика мовних одиниць, Філологічні студії”, Київ 2011, вип. 6, с. 249-254.

Космеда T., Ego i Alter Ego Tapaca Шевченка в комунікативному просторі щоденникового дискурсу, Дрогобич 2012.

Костенко Л. В., Триста поезій, Київ 2012.

Крохмальна Г. І., Терміни в ідіостилі вченого, автореф. ... канд. філол. наук, Львів 2011.

Мацько Л. І., Мовна особистість Андрія Малишка як лінгвокультурологічний феномен національного виховання у світлі лінгвофілософiї, [в:] „Науковий часопис НПУ імені М. П. Драгоманова", сер. 16: Творча особистість учителя: проблеми теорії $і$ практики, Київ 2013, вип. 20, с. 141-146.

Мельник М. Р., Ономастика творів Ліни Костенко, автореф. дис. ... канд. філол. наук, Одеса, 1999.

Петрова Л. П., Власне ім'я як засіб інтелектуалізаиії (на матеріалі поезї Ліни Костенко), автореф. дис. ... канд. філол. наук, Харків 2003.

Ужченко В. Д., Ужченко Д. В., Фразеологія сучасної української мови, Київ 2007. 


\section{Spysok vykorystanoi literatury \\ [References]}

Buts N. V., Spetsyfika mentalnoho leksykonu: movnyi etyket u tvorakh Liny Kostenko [Specificity of Mental Lexicon: Language Etiquette in Poetry by Lina Kostenko], [v:] „Uchenie zapysky Tavrycheskoho natsyonalnoho unyversyteta ym. V. Y. Vernadskoho”, seryia „Fylolohyia. Sotsyalnie kommunykatsyy”, t. 24 (63), Symferopol 2011, № 4, ch. 1, s. 431-434.

Hubareva H. A., Semantyka ta stylistychni funktsii koloratyviv u poetychnii movi Liny Kostenko [Semantic and Stylistic Functions of Colour Distinction in Poetic Language by Lina Kostenko], avtoref. dys. ... kand. filol. nauk, Kharkiv 2002.

Zahnitko A., Zahnitko N., Teoriia suchasnoi linhvopersonolohii: rivni y katehorii [Theory of Modern Linguo-Personology: Levels and Categories], [v:] „Studia Ukrainica Posnaniensia", red. nauk. T. Kosmeda, 2016, zesz. IV, s. 17-20.

Karaulov Yu. N., Russkij yazyk i yazykovaya lichnost' [The Russian Language and Language Personality], Moskva 1987.

Kasianenko N. M., Kontsept slovo v poetychnii kartyni svitu Liny Kostenko [Concept "Word" in Poetic World Image by Lina Kostenko], [v:] „Visnyk Donetskoho natsionalnoho universytetu, Ser. B: Humanitarni nauky”, 2013, vyp. 1-2, t. 1, s. 120-126.

Kevliuk I. V., Termin frazema $v$ etnolinhvistytsi ta kulturolohii [Term "Phraseme"in Ethnolinguistics and Culturology], [v:],,Struktura i semantyka movnykh odynyts, Filolohichni studii", Kyiv 2011, vyp. 6, s. 249-254.

Kosmeda T., Ego $i$ Alter Ego Tarasa Shevchenka $v$ komunikatyvnomu prostori shchodennykovoho dyskursu [Ego and Alter Ego of Taras Shevchenko in Communicative Space of Diary Discourse], Drohobych 2012.

Kostenko L. V., Trysta poezii [Three Hundred Poems], Kyiv 2012.

Krokhmalna H. I., Terminy v idiostyli vchenoho [Terms in Idio-Style of a Scientist], avtoref. ... kand. filol. nauk, Lviv 2011.

Matsko L. I., Movna osobystist Andriia Malyshka yak linhvokulturolohichnyi fenomen natsionalnoho vykhovannia u svitli linhvofilosofii [Language Personality of Andriy Malyshko as Linguo-Culturological Phenomenon of National Education through the Prism of Linguo-Philosophy], [v:] „Naukovyi chasopys NPU imeni M. P. Drahomanova”, ser. 16: Tvorcha osobystist uchytelia: problemy teorii i praktyky, Kyiv 2013, vyp. 20, s. $141-146$.

Melnyk M. R., Onomastyka tvoriv Liny Kostenko [Onomastics of Lina Kostenko Works], avtoref. dys. ... kand. filol. nauk, Odesa, 1999.

Petrova L. P., Vlasne imia yak zasib intelektualizatsii (na materiali poezii Liny Kostenko) [Proper Name as Means of Intellectualization (Based on Lina Kostenko's Poetry], avtoref. dys. ... kand. filol. nauk, Kharkiv 2003.

Uzhchenko V. D., Uzhchenko D. V., Frazeolohiia suchasnoi ukrainskoi movy [Phraseology of Modern Ukrainian], Kyiv 2007. 